\title{
Carbon nanospheres as an electrode material for electroadsorption of $\mathrm{Cu}$ (II)
}

\section{Las nanoesferas de carbono como material de electrodo para la electroadsorción de $\mathrm{Cu}$ (II)}

\author{
KASHINA, Svetlana ${ }^{1} \uparrow$, BALLEZA, Marco ${ }^{2}$, JACOBO-AZUARA, Araceli ${ }^{1}$, GALINDO-GONZÁLEZ, \\ $\operatorname{Rosario}^{3 *}$
}

${ }^{I}$ Universidad de Guanajuato, Natural and Exact Sciences division, Department of Chemistry

${ }^{2}$ Universidad de Guanajuato, Science and Engineering division, Department of Physics

${ }^{3}$ CONACYT cathedra in Universidad de Guanajuato, Natural and Exact Sciences division

ID $1^{\text {st }}$ Author: Svetlana, Kashina / ORC ID: 0000-0003-4277-2060, CVU CONACYT ID: 516653

ID $1^{\text {st }}$ Coauthor: Marco, Balleza / ORC ID: 0000-0002-3246-0277, CVU CONACYT ID: 406536

ID $2^{\text {nd }}$ Coauthor: Araceli, Jacobo-Azuara / ORC ID: 0000-0003-0967-1858, CVU CONACYT ID: 104385

ID $3^{\text {rd }}$ Coauthor: Rosario, Galindo-González / ORC ID: 0000-0002-3612-1555, CVU CONACYT ID: 223987

DOI: $10.35429 /$ EJB.2019.11.6.17.19

Received: July 09, 2019; Accepted: September 23, 2019

\begin{abstract}
Objectives. Contamination with heavy metals has augmented in last decades due to several factors. So, scientific community has a challenge to develop new and more efficient methods for contaminants removal. Electroadsorption is one of investigated techniques with promising results. The main challenge with this technique is determination of optimal parameters, such as electrode material, time and conditions of adsorption. Material for electrode for electroadsorption must fulfil some criteria: high electroactive area, low electrical resistance and environmental compatibility. For that reason, our research group decided to synthetize a set of new carbon materials with high surface area and features than make them interesting to test them as an electrode material. Methodology. 3 carbon materials were synthetized by sol-gel method using different time and temperature conditions. All materials were characterized by scanning electron microscopy and other techniques. FTO glasses were modified with synthetized materials separately. Electroadsorption of $\mathrm{Cu}$ (II) was conducted at room temperature. Contribution. In this work we demonstrate an easy synthesis of 3 carbonaceous materials with high surface area capable to remove $\mathrm{Cu}$ (II) from water solution by electroadsorption.
\end{abstract}

Carbone nanospheres, Electroadsorption, Copper

\begin{abstract}
Resumen
Objectivos. La contaminación con metales pesados ha aumentado debido a varios factores. Por lo tanto, la comunidad científica tiene el desafío de desarrollar métodos nuevos y eficientes para la eliminación de contaminantes. La electroadsorción es una de las técnicas con resultados prometedores. El desafío con esta técnica es la determinación de parámetros óptimos, como el material del electrodo y las condiciones de adsorción. El material de electrodo para la electroadsorción debe cumplir con algunos criterios: alta área electroactiva, baja resistencia y compatibilidad ambiental. En el grupo de trabajo se sintetizan nuevos materiales de carbono con características que los hacen interesantes para probarlos como material de electrodo. Metodología. Se sintetizaron 3 materiales de carbono mediante el método sol-gel utilizando diferentes condiciones de tiempo y temperatura. Todos los materiales se caracterizaron mediante microscopía electrónica de barrido y otras técnicas. Los vidrios FTO fueron modificados con materiales sintetizados. La electro-absorción de $\mathrm{Cu}$ (II) se realizó a temperatura ambiente. Contribución. La síntesis del material es sencilla, de bajo costo y amigable con el ambiente. Se muestran resultados para 3 materiales carbonosos con un área de superficie alta y capaz de remover $\mathrm{Cu}$ (II) de una solución acuosa mediante electro absorción.
\end{abstract}

Nanoesferas de carbono, Electroadsroción, Cobre

Citation: KASHINA, Svetlana, BALLEZA, Marco, JACOBO-AZUARA, Araceli, GALINDO-GONZÁLEZ, Rosario. Carbon nanospheres as an electrode material for electroadsorption of Cu (II). ECORFAN Journal-Bolivia 2019. 6-11: 17-19

\footnotetext{
* Correspondence to Author (email: galindorosario@gmail.com)

$\dagger$ Researcher contributing as first author.
} 


\section{Introduction}

Environmental contamination with heavy metals due to variety of factors is a great problem. This contamination causes negative effect of ecosystems and human health. Copper intoxication is relatively rare condition, but its incidence have augmented in recent years because of the increase of copper concentration in waste waters.

Conventional methods such as active mud formation and precipitation of metals are not good strategy for copper removal, because the majority of copper salts are soluble in water. Electroadsorption may be the best option because its low cost and simple equipment.

The main challenge with this method is optimization of parameters of the process, such as material for electrodes, time, temperature and others.

Electrode material must meet some criteria: it should present high active area, los resistance to electric current and be environmentally friendly.

Carbon materials meet some specified criteria, but usually lack high surface area. To solve this problem, nanometric forms of carbon are developed.

Carbon nanospheres are relatively new form of carbon, and it possesses high surface area. Carbon nanospheres can be produced by variety of methods, but sol-gel synthesis is one of the best options due to scalability and controllability of the process.

Sol-gel synthesis of carbon nanospheres was described by Liu a al in 2011. It involves several steps, including gel formation $y$ maturation for several hours. This process is time and energy consuming, so it is not easily applicable in industry.

For his reason, our research group decided to investigate an influence of reduction of time of synthesis and different temperature conditions on properties of resulted materials. Also, synthetized carbon nanospheres were assessed as electrode materials for $\mathrm{Cu}$ (II) electroadsorption.

\section{Methodology}

Synthesis. Carbone nanospheres were synthetized using methodology described by Liu et al in 2011 with some modifications. First polymeric spheres were produced by sol-gel process. Resorcinol was dissolved in mixture of water, ethanol and ammonium as a catalyst. Then formaldehyde was added drop by drop. Resulted mixture was left in stirring conditions for different time and under different temperature. After that, solid phase was separated by centrifugation, washed with water and ethanol, and dried overnight at $100{ }^{\circ} \mathrm{C}$. Dry powder was carbonized separately in tubular oven at $900{ }^{\circ} \mathrm{C}$ for $3 \mathrm{~h}$. Black material was recollected from the oven and named as SG-1, SG-2 and SG-3. General scheme of synthesis is presented in figure 1 .

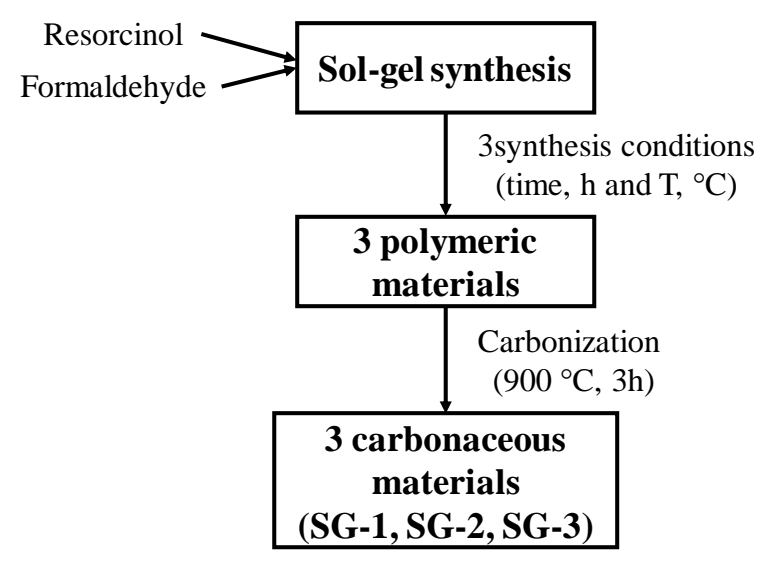

Figure 1 General scheme of synthesis of carbon nanospheres

Characterization. Scanning electron microscopy was performed for all 3 materials. Also, materials were characterized by FTIR an RAMAN spectroscopy. Surface area of materials was assessed by nitrogen adsorptiondesorption.

$\mathrm{Cu}$ (II) removal. Electroadsorption was performed in neutral water solution of $20 \mathrm{ppm}$ of $\mathrm{Cu}$ (II). FTO covered glasses were modified with carbon materials and used as electrodes. $2 \mathrm{~V}$ constant voltage electrical current was applied to the system for 1-12 h. Percentage of $\mathrm{Cu}$ (II) removal was calculated as follows:

$\%$ of removal $=$

$\frac{\text { (Inicial concentration-final concentration }}{\text { inicial concentration }} * 100 \%$ 


\section{Results}

3 carbonaceous materials were synthetized. Scanning electron microscopy have shown that particles of all 3 materials present perfectly spherical shapes with $700 \mathrm{~nm}$ diameter, approximately.

FTIR spectra for all materials did not reveal peaks corresponding to any functional group, that was expected due to high temperature of carbonization. RAMAN spectra shown 2 peaks: $G$ band at $1590 \mathrm{~cm}^{-1}$ than corresponds to $\mathrm{sp}^{2}$ configuration and $\mathrm{D}$ band at $1310 \mathrm{~cm}^{-1}$ that is typical for amorphous carbon. So, all three synthetized materials are carbon nanospheres without significant number of functional groups and are not completely amorphous.

Results of physisorption of nitrogen have shown that materials possess specific surface area of approximately $440 \mathrm{~m}^{2} / \mathrm{g}$ and are microporous.

Electroactive coverage prepared from materials separately have shown good adherence to FTIO covered glasses and did not detached from the surface during electroadsorption process. After desired time of adsorption was achieved, accumulation of metallic copper on the surface of electrodes was visible.

Table 1 comprises percentages of removal of $\mathrm{Cu}$ (II) from water solution. For all studied materials removal of approximately $30 \%$ of initial concentration was achieved after $12 \mathrm{~h}$ of the process.

\section{Conclusions}

Carbon nanospheres were synthetized avoiding gel maturation step without loss of shape and specific surface area. This omission allows to reduce time and cost of mass scale production of these materials. Also, synthetized materials were evaluated as electrode material for electrochemical removal of $\mathrm{Cu}$ (II) with acceptable results.

Functionalization of synthetized materials with different methods should be assessed in order to improve performance in electroadsorption.

\begin{tabular}{|l|r|r|r|}
\hline \multirow{2}{*}{ Time of } & \multicolumn{3}{|c|}{ Cu (II) removal (\%) } \\
Electroadsorption (h) & SG-1 & \multicolumn{1}{|c|}{ SG-2 } & \multicolumn{1}{c|}{ SG-3 } \\
\hline 1 & 9 & 18 & 5 \\
\hline 2 & 15 & 21 & 12 \\
\hline 3 & 15 & 21 & 12 \\
\hline 4 & 18 & 24 & 14 \\
\hline 5 & 18 & 24 & 16 \\
\hline 6 & 18 & 27 & 16 \\
\hline 7 & 21 & 27 & 19 \\
\hline 8 & 24 & 27 & 19 \\
\hline 9 & 24 & 27 & 21 \\
\hline 10 & 27 & 30 & 26 \\
\hline 11 & 27 & 30 & 26 \\
\hline 12 & 30 & 33 & 28 \\
\hline
\end{tabular}

Table 1 Removal of $\mathrm{Cu}$ (II) from water solution by electroadsorption

\section{References}

Bergmann, C. P., \& Machado, F. M. (Eds.). (2015). Carbon nanomaterials as adsorbents for environmental and biological applications (pp. 1-122). Berlin: Springer.

Liu, J., Qiao, S. Z., Liu, H., Chen, J., Orpe, A., Zhao, D., \& Lu, G. Q. (2011). Extension of the Stöber method to the preparation of monodisperse resorcinol-formaldehyde resin polymer and carbon spheres. Angewandte Chemie, 123(26), 6069-6073. 